\title{
Paideusis
}

\section{Redefining Success}

\section{Carlo Ricci}

Volume 16, Number 1, 2007

URI: https://id.erudit.org/iderudit/1072606ar

DOI: https://doi.org/10.7202/1072606ar

See table of contents

Publisher(s)

Canadian Philosophy of Education Society

ISSN

0838-4517 (print)

1916-0348 (digital)

Explore this journal

Cite this article

Ricci, C. (2007). Redefining Success. Paideusis, 16(1), 47-53.

https://doi.org/10.7202/1072606ar

\section{Article abstract}

Two interconnected arguments are made: 1) that we eliminate standardized testing 2) that we oppose mainstream schooling. Schooling and education are two very different concepts, and do not necessarily coincide in practice. A case in point: our current schooling system is anti-educational. This paper makes the case for unschooling and learner-centred democratic alternatives. (c) Carlo Ricci, 2007

(c) (i)
This document is protected by copyright law. Use of the services of Erudit (including reproduction) is subject to its terms and conditions, which can be viewed online.

https://apropos.erudit.org/en/users/policy-on-use/ 


\title{
Redefining Success
}

\author{
CARLO RICCI \\ Nipissing University, Canada
}

Two interconnected arguments are made: 1) that we eliminate standardized testing 2) that we oppose mainstream schooling. Schooling and education are two very different concepts, and do not necessarily coincide in practice. A case in point: our current schooling system is anti-educational. This paper makes the case for unschooling and learner-centred democratic alternatives.

\section{Yours Impressionistically,}

I recently returned from China, and while there, I had the good fortune of visiting the beautiful city of Guilin. From Guilin, I took a boat down a swiftly flowing river to Yangshuo. In Yangshuo, I saw a powerful production titled "Impressions of the Third Sister Liu," a light-and-dance show performed under the stars with the river as the stage. It was not thematic, but was instead meant to create an impressionistic effect. Yimou Zhang, the director of Hero, directed it. I hope that this paper about alternatives that redefine schooling and education will leave you with impressions that are just as strong.

In this paper I want to make two points clear:

1) We need to eliminate standardized testing.

2) We need to argue for education and against mainstream schooling.

Let me start off by screaming that schooling and education are two very different concepts. They are not the same thing at all. Even more forcefully, I wish to make the point that our current schooling system is anti-educational. In Learning All The Time, John Holt (1989) has a section titled "Living as Learning" in which he writes:

Living is learning. It is impossible to be alive and conscious (and some would say unconscious) without constantly learning things. If we are alive we are receiving various sorts of messages from our environment all the time. (p. 157)

Holt's definition of learning as living is the best definition of education that I have come across. Although Holt rejects the term "education" because of its connection to schooling, I want to use the term as a way of reappropriating it. Indeed, how did "learning" and "education" come to mean two different things? Marketers could not sell nutritionless white bread products without first being able to separate wheat germ and bran from the starch inside the kernel. Education specialists could not monopolize teaching without first convincing folks that natural (and free) learning is not the same as formal (and costly) education. So, although Holt and I disagree about whether we should use the words "education" and "learning" interchangeably, we agree that living is learning. I would say that education

(C) Copyright 2007. The author, Carlo Ricci, assigns to Paideusis the right of first publication and educational and non-profit institutions a non-exclusive license to use this document for personal use and in courses of instruction provided that the article is used in full and this copyright statement is reproduced. Any other usage is probibited without the express permission of the author. 
is living, and that as we live education happens. I shall observe here that schooling has created a rift between education and education as living. Too many assume that education is the same as schooling. Illich (1983) writes, "School prepares for the alienating institutionalization of life by teaching the need to be taught" (p. 67). Schools, merely by existing and being imposed on us, disempower us, since they make us believe that we need to go to school to learn and that we cannot learn on our own.

I argue for a radically different perspective on curriculum, assessment and evaluation. The perspective I will share is a learner-centred, democratic and holistic approach which insists that individuals choose their own curriculum and that we do away with assessment and evaluation. To help clarify what I mean, I am using the terms "learner-centred" and "democratic" in a way that Jerry Mintz (2004) does when he defines learner-centred education as "an approach that is based on the interest of the student rather than curriculum driven, where someone else has the idea of what you ought to be learning." Moreover, he defines democratic education as "education where students are actually empowered to make decisions about their own education and, if they are in a school, their own school." And I am using "holistic" to mean a curriculum that focuses on the interconnection of body, mind, and spirit.

To further clarify and bolster my position and hopefully leave strong impressions on the reader, I will quote Dewey, Rousseau, and Ron Miller on Steiner. I want to first introduce a quote from John Holt to accentuate the contrast between him and these other thinkers. John Holt (1989) writes, “... any teaching that the learner has not asked for is likely to impede and prevent his or her learning" (p. 28). For Holt, the learner is in control. Now, contrast this with what Dewey (1963) writes:

The greater maturity of experience which should belong to the adult as educator puts him in a position to evaluate each experience of the young in a way in which the one having the less mature experience cannot do. It is then the business of the educator to see in what direction an experience is heading. There is no point in his being more mature if, instead of using his greater insight to help organize the conditions of the experience of the immature, he throws away his insight. (p. 38)

Similarly, Rousseau (1957) says, in relation to the child:

Let [the child] always believe he is the master, and let it always be you who are. There is not subjection so perfect as that which keeps the appearance of freedom.... Doubtless he ought to do only what he wants; but he ought to want only what you want him to do. He ought not to make a step without your having foreseen it; he ought not to open his mouth without your knowing what he is going to say.... Thus, not seeing you eager to oppose him, not distrusting you, with nothing to hide from you, he will not deceive you, he will not lie to you, he will fiercely show himself precisely as he is. You will be able to study him at your complete ease and arrange all around him the lessons you want to give him without his ever thinking he is receiving any. (p. 120)

In line with Dewey and Rousseau, Ron Miller (1995) argues during his summarization of Rudolf Steiner's Waldorf education that:

The Waldorf educator sees unbounded freedom for young children as premature, as violating their innate developmental needs. The Waldorf approach is grounded in the understanding that the growing child possesses an unfolding spiritual identity, which can be nourished with loving yet firm guidance. According to this developmental view, human capacities are inherent, but they require cultivation and discipline in order to be expressed to their fullest measures. (p. 8)

In short, Holt argues, along with Mintz, that education should be learner-centred. Again, Mintz defines learner-centred education as "an approach that is based on the interest of the student rather than curriculum driven, where someone else has the idea of what you ought to be learning," whereas, 
the others place the control on external agents. I, of course, agree with Holt and Mintz, and not with the others. Again, we need to remind ourselves of the difference between schooling and education. I repeat, they are not the same things; and, in fact, I would argue that mainstream schooling is antieducational.

\section{Against Standardized Testing}

Here are two examples from the China Daily that highlight my points against standardized testing and mainstream schooling, and in favour of education. When I was in China I was happy to read in the China Daily of a father and teacher who was home schooling his child, and I was sad to read that he was encountering a lot of resistance. His son was successful in many areas, but schooling was getting in the way. For example, his son was a successful chess player who was winning many tournaments. I was also sad to read about a student who committed suicide after failing the English College Entrance Exam. As well, graduate students in Shanghai and Guangdong committed suicide because of the pressures of modern schooling. These tragic incidents happen in our system as well. We are not immune to the casualties and tragedies of schooling. Evidence of this is present in the news on a daily basis. I am reminded of how Gatto (2003) impresses upon us his notion of schooling, as aptly captured in the subtitle of his book, namely "the prison of modern schooling."

Ben Feller's (2006) article is a clear example of how arbitrary standardized tests are. He writes, "In Mississippi, 89 percent of fourth-graders who took a state reading test were rated proficient or better. But when the same students took a federal test, only 18 percent reached that standard." How well are these students doing? Obviously, the answer to this question depends on which test we use. The sad part about this is that in certain high-stakes tests a person's future can be redirected by using one test over another. The manipulation and determination of children's futures based on such arbitrary tests that measure a limited and often meaningless set of skills is, to my mind, unethical. Illich (1983), in pointing out how "Man has become the plaything of scientists, engineers, and planners" (p.160) correctly expresses a scary and sad commentary about our contemporary world.

In the past, I have written about the flaws of standardized testing (Ricci, 2004a); the impossibility of comparing one year's scores to the next because of changes to the standardized tests (Ricci, 2005); the narrowing of the curriculum (Ricci, 2004b); the anxieties and frustrations of standardized testing (Ricci, 2005). (For example, a student shared with me that when he was in grade three he was so nervous and anxious because of the test that he developed coin-sized bald spots on his head. His mother shared the same story with me during her interview.) I have heard other people (for example, psychometricians Michael Jodoin (2005) of the educational testing services and Ruth Childs (2005) of the Ontario Institute for the Study of Education at the University of Toronto) speak on the flaws of standardized testing. As well, I have read many arguments challenging standardized testing.

While in China and Cameroon, I witnessed the dangers of standardized testing in other countries. For example, in China children cannot enter the 'best' schools that possess the most resources unless they do well on a standardized test; and, of course, those who do well on the test are those who are already advantaged. The problems there parallel our problems. It's not the way in which we do standardized testing that is the problem, but rather standardized testing itself is an evil.

In the one study that Taylor and I conducted (Ricci and Taylor, 2004), where we looked at student anxieties and frustrations, one student felt so ashamed of his lack of success on the test that he hid the results and lied to his parents about them. When we called the parents, his mother said that the results had not been released yet, but I knew that the school had already mailed them out. The student similarly told me that the results had not been released yet. It was obvious that the student had intercepted the mail to spare himself shame and spare his parents anxiety and disappointment. Driving children to act in this way and making them feel so anxious and frustrated are reasons enough to eliminate this unethical, flawed and fictitious test that reduces human beings into playthings. 
Standardized testing makes people ill, and insofar as you and I accept the practice and continue to enact it, we must take responsibility for such illnesses.

Eisner (1998) sums it up best when he argues that it is possible to raise test scores and diminish education at the same time. We have to ensure that we do not confuse higher test scores with a better system of education or of schooling. In a paper that I wrote (Ricci, 2005) I argued that higher test scores do not correlate with higher student achievement-as asserted by those in the government and others who promote testing-but is more likely a result of policy changes surrounding, in part, the administration of the test.

In this paper, I would like to advance a moral or ethical argument by asking the following questions: Do we have the right to control what people learn? To dictate what they should be interested in? To play omnipotent beings who can determine what knowledge is of most worth and what knowledge will open up doors? Should we pretend that we are omniscient and that we can predict people's future potential? Should we act as gatekeepers? Should we ignore out-of-school factors like standardized testing? Schooling thrives at the expense of students' lives.

At the 2005 People for Education Conference, one speaker said that only approximately $20 \%$ of a student's achievements is a result of schooling, and the rest is a result of out-of-school factors. If this is the case, what are we measuring when we use standardized testing? Is it achievement, as proponents of testing claim, or are we continuing to punish people by measuring their out-of-school factors while claiming that we are objectively measuring achievement? When I sit and listen to stories of the abuses children have suffered and then think about how these tests and schooling are blind to these abuses, I am convinced that we are morally and ethically bankrupt. We are all guilty. We should be screaming and challenging these injustices until they are eliminated; and if we don't, we are implicated in perpetuating these injustices.

To make all of this worse, there are errors in standardized testing. For example, here a list of the findings of some recent articles: college board-more SAT scoring errors revealed; college board understates scores for 1000s of students; college board won't reveal overstated SAT scores; handscoring of tests leads to different results; SAT scoring errors shake confidence in testing; student sues over SAT error; wrong scores shake up schools.

\section{With Respect to Education over Schooling}

At this point I would like to share with you my personal history with schooling to illustrate using a firsthand account the harmful effects of an externally imposed curriculum and of assessment and evaluation. As most of the readers here would know, schooling is a recent development in our history, and perhaps the most dangerous invention that schools have developed is assessment and evaluation.

My own history with schooling is one filled with turmoil and oppression. This is just a brief example of how I was abused by schooling. As a student, I felt like a caged tiger. Now I feel somewhat released. The reason I say "somewhat" is that I still work for an educational institution, and I am still bound by their control over me. (See my forthcoming book, Poisoned Apples, for more details.) Even in graduate school my mind was being occupied and preoccupied by other people's thoughts and interests. Since I graduated I am now doing more of my own thing. Students think that I have a degree in Alternative Schooling since this is where I focus a lot of attention. The truth is that everything that I am now focused on and interested in, I learned on my own. Schooling was in my way. Since I left schooling I am now more liberated to explore my own interests rather than someone else's.

You know the system is flawed when someone who is a doer and knows more about alternatives to schooling than I do cannot have my job. For example, Jerry Mintz is a doer. I would like to learn from him, but he cannot have my job because he does not have a Ph.D. This is absurd. He knows more about Alternative Education than I do, has written books, started schools, run a school, runs an 
organization, and so on. Something is wrong when it's not about what you know, but about the paper or certificate you hold.

\section{What Do We Need to Do?}

In On MisEducation Noam Chomsky (2000) points out that those who exercise control over the educational apparatus are commissars of the system:

Those who exercise control over the educational apparatus should be referred to as a class of "commissars." Commissars are the intellectuals who work primarily to reproduce, legitimate, and maintain the dominant social order from which they reap benefits. Real intellectuals have the obligation to seek and tell the truth about things that are important, things that matter. (p. 26)

We have to ensure that we are not commissars, and that we are not part of the problem but rather part of the solution.

We cannot be intimidated. After I wrote "Breaking the Silence" I was asked to be an affiant in a court case challenging the Education Quality and Accountability Office (the body, at arms-length from the government, that is largely responsible for standardized testing in Ontario's schools). As part of this process I was questioned by a government lawyer who challenged my right to write the piece. (I may write about this inquisition at some point in the future.) After writing the piece I received a lot of attention from television, radio and newspapers. People were interested in what I had to say, yet I felt like my perspective was not welcomed by those in power. We live in a culture where we are discouraged from speaking against the system. Those in positions of power try to silence any oppositional views. We see this with the Harper government's battle with the media, and I see it in my own personal experience and in the experiences of my students. To cite another example, one of my graduate students is afraid to write her thesis about her experience with the Turnaround program because she is afraid for her job and is afraid that she will get into trouble. The Turnaround program is one in which the Ontario Ministry of Education sends a turnaround team to schools that have scored poorly on the EQAO standardized test score, to help them do better the next time around. She was made to sign a confidentiality clause and was told that whatever she wrote about this topic needs to be approved by the Ministry. We like to think that we live in a democracy and that as part of that privilege we are free to share and expose injustices when we see them. I have come to believe that this is not the case. Nevertheless, if we believe in democracy we need to challenge injustices and not be afraid.

As well, it becomes dangerous when those in positions of power claim neutrality. At a session at the CSSE in 2005, I was talking to the session leaders, who were from the Ontario College of Teachers (OCT), about the OCT. I mentioned to them that the Standards of Practice and the Ethical Standards reflect a particular bias and that we cannot ignore this. In short, they denied this and said that the test is so broad in scope that it does not have a bias. When we are not aware of the bias in our frameworks a dangerous situation is set up in which our position is seen as the natural, unquestionable truth.

There is hope. There are examples of schools that I urge everyone to get to know more intimately: Sudbury Valley Schools, Albany Free School, Fairhaven, and the Beach School, to name just a few. These are learner-centred democratic schools. In contrast to these learner-centred democratic schools, mainstream schools are violent places where children are not allowed to blossom, but are instead moulded (see my forthcoming book: Schools Kill).

Many studies show that having a degree means that you earn more money in your lifetime. However, just because you do not have a degree does not mean that you are not capable, it just means that you are barred. For example, one woman I know successfully runs a huge company. She has been doing it for over 25 years. There is the owner who is retired and then there is her. She barely finished 
high school. If her job became vacant and she subsequently applied for the very same job that she is in and has been successfully doing for a long time she would not even get an interview. You need someone with an MBA or EMBA to run a company like this, the myth goes. There is something not right about this.

We need to seriously ask ourselves whether students can have a good life without a degree. Think of the many inventors who are largely unschooled in their fields. Many don't have a degree, but they have passion and grit. Gatto (2005) talks about how, when he went to China, he noticed that three of the biggest industries that are influencing their economy and culture (namely, the computer, fast food, and entertainment industries) were started by school dropouts.

The emphasis on schooling and being capable I take personally. My parents and many around me who are among my greatest advisors have very little schooling, but they are very educated. Quite often, when I need help and advice, it is to elementary school dropouts that I turn. We are in a critical period where we are increasingly losing the voices of those who are not schooled but who are clearly educated. I asked my graduate students about their parents' history with schooling. I thought that after I surveyed them I would be able to say, "You see, most of your parents are high school dropouts." What in fact happened was that most of their parents were not high school dropouts, but elementary school dropouts. However, the younger students' parents had the most education.

There are now alternative universities, alternative ways of getting into university without a high school diploma, and so on. There is hope. By the way, I also want to remind you that many people who we consider to have made successful contributions to our world are school dropouts. For example, Jane Jacobs, Peter Jennings, and Buzz Hargrove are all school dropouts, yet highly educated, influential and successful.

I would like to end with a quote from an article by Sandra Martin (2006) lauding Jane Jacobs. It reads:

By the time she had completed high school, she was "thoroughly sick of attending school and eager to get a job."... Her parents wanted her to go to university so she went to the School of General Studies at Columbia for two years, but left after she ran afoul of university required courses for completing a degree. And so she continued her own idiosyncratic process of selfeducation by reading, observing, wondering, thinking and trying to assemble her thoughts in a coherent piece of writing.

I would also like to remind the reader of Jacobs' message about the spirit with which we need to approach the battle. John Barber (2006) writes:

Appropriately it was in church when Ms. Jacobs moved me most: St. James Cathedral, Feb. 24, 1997, during an address to one of the hundreds of spontaneous protest meetings that swept the city in response to the Harris government's epochal exercise in municipal amalgamation and impoverishment. Scathing, hilarious and clear-eyed as ever, she warned that there was "reason to feel grim" about the future. "But a battle like this would be intolerable if we didn't have a good time, if we didn't have the joy of battle, if we didn't have a high old time in this fight," she said, as hearts rose and a thousand faces beamed. "Never, never underestimate the power of high hearts when they're combined with principled, unyielding wills."

\section{References}

Barber, R. J. (2006, April 26). Fond farewell to an urban prophet. The Globe and Mail, p. A1.

Childs, R. (2005, May). Report card on educational measurement in Canada. Paper presented at the Canadian Society for the Study of Education at The University of Western Ontario, London, Ontario.

Chomsky, N. (2000). On miseducation. Lanham, Maryland: Rowman \& Littlefield Publishers, Inc. 
Dewey, J. (1963). Experience and education. New York: Macmillan.

Eisner, E. (1998). "The role of teachers in education and assessment reform." Speech presented at the BCTF AGM, March 1998. Retrieved May 11, 2005, from http://www.bctf.bc.ca/ publications/speeches/eisner.html

Feller, B. (2006, March 3). Gaps appear in state, federal test scores. Boston.com. Retrieved April 3, 2006, from http://www.boston.com/news/education/k_12/articles/2006/03/03/gaps_appear_in_ state_federal_test_scores/

Gatto, J.T. (2003). The underground history of American education: An intimate investigation into the prison of modern schooling (Rev. ed.). Oxford, New York: The Oxford Village Press.

Gatto, J.T. (2005, September/October). Breaking from the herd. Life Learning, 14-17.

Holt, J. (1989). Learning all the time: How small children begin to read, write, count, and investigate the world, without being tanght. Cambridge, MA: Da Capo Press.

Illich, I. (1983). Deschooling society. New York, New York, Harper and Row Publishers. (Original work published 1970).

Jodoin, M. (2005, May 28). Report card on educational measurement in Canada. Paper presented at the Canadian Society for the Study of Education at The University of Western Ontario, London, Ontario.

Martin, S. (2006, April 26). Jane Jacobs, writer, urban planner, activist: 1916-2006. The Globe and Mail, p. A1.

Miller, R. (1995). Freedom in a holistic context. Holistic Education Review, 8 (3), 4-11.

Mintz, J. (Speaker). (2004, July 28). Building democratic schools. Radio Free School. Retrieved November 25, 2005, from http://www.radio4all.net/pub/archive/04.01.05/ grassroots@hwcn.org/125-120040729-0728rfsc10.mp3

Ricci, C. (2004a, October-December). The case against standardized testing and the call for a revitalization of democracy. The Review of Education, Pedagogy, and Cultural Studies, 26(4), 339-361.

Ricci, C. (2004b, Winter). "Breaking the silence: a marker speaks out against standardized testing." Our Schools/Our Selves, 13 N.2 (\#74), pp. 75-88.

Ricci, C. (2005, Summer). 2005 EQAO scores up, artificially? Our Schools/Our Selves, 14(4) \#80, 75-81.

Ricci, C. (2006). Poisoned Apples: An insider exposes the victimization, abuse, politics, associated pain and SOLUTIONS to our educational crisis. Manuscript submitted for publication.

Ricci, C. (Forthcoming). Schools (K)ill: How architecture, unhealtby foods, poor air and water quality, germs, and violence threaten our children. Alternative Press.

Ricci, C., \& Taylor, S. (2004, Fall). Challenging the Validity of Standardized Testing. Our Schools/Our Selves, 14(1), (\#77), 73-73.

Ricci, C., \& Taylor, S. (2005, May). Ontario high stakes testing: Anxieties and frustrations. Paper presented at the Canadian Society for Studies in Education.

Rousseau, J.J. (1957). Emile (B. Foxley, Trans.). New York: E.P. Dutton.

\section{About the Author}

Carlo Ricci teaches in Nipissing University's Faculty of Education, and he says, "Everything of value that I have learned, I have learned outside of formal schooling." His research interests include: the erosion of democracy in our education system and an advocacy for its revitalization; teaching literacy using the spirit of Paulo Freire's pedagogical assumptions; democratic education; critical theory; holistic education; social justice issues; alternative schools; unschooling; assessment and evaluation; the double cohort; and the negative impact of standardized testing. Ricci is also the editor of the Journal of Unschooling and Alternative Learning (JUAL): http://www.nipissingu.ca/jual/index.asp. His personal website is: http://www.nipissingu.ca/education/carlor/ 